\title{
Converting Education into Earnings: The Patterns among Hispanic Origin Men
}

\author{
LiSA J. NeIDERT \\ Population Studies Center, University of Michigan
}

AND

Marta Tienda

Department of Rural Sociology and Center for Demography and Ecology, University of Wisconsin, Madison

\begin{abstract}
We evaluate the functional form of the relationship between education and earnings for Hispanic and non-Hispanic white men to determine whether the payoffs to education vary with level of schooling, and whether credential effects can be discerned. Results indicate that for all groups the usual linear specification, while offering the advantage of parsimony, fits the data less well than more complex models. The levels model best predicts the earnings of Puerto Rican and other Spanish origin workers, while the credential model is best suited for Mexican, Central/South American, and non-Hispanic white men. Credential effects accrue to all groups, except the other Spanish, but Central/South Americans only receive added income bonuses for the completion of a college degree, whereas Mexican, Pucrto Rican, and non-Hispanic white mon also receive a bonus for a high school diploma. (c) 1984 Academic Press. Inc.
\end{abstract}

Although there exists a wealth of literature about the economic benefits of education (Schultz, 1963; Becker, 1964; Blau and Duncan, 1967; Psacharopoulos and Hinchliffe, 1973; Mincer, 1974; Sewell and Hauser, 1975; Featherman and Hauser, 1978), most analyses focus on white men or comparisons between black and white men (Siegel, 1965; Day, 1967; Thurow, 1969; Weiss, 1970; Farley and Hermalin, 1972; Weiss and

This research was supported by a grant from the U.S. Department of Labor (21-55-7927) with additional funds from the Institute for Research on Poverty, the Graduate School Research Committee, and the College of Agricultural and Life Sciences of the University of Wisconsin, Madison. Computational work was supported by a grant to the Center for Demography and Ecology from the Center of Population of NICHD (HD-05876). Send requests for reprints to Marta Tienda, Department of Rural Sociology. University of Wisconsin. 350 Agriculture Hall, 1450 Linden Drive, Madison, WI 53706. 
Williamson, 1972; Blinder, 1973; Morgenstern, 1973; Flanagan, 1974). Only a few studies have explicitly examined the returns to education among Hispanic men, and most of these (Fogel, 1966; Grebler, Moore, and Guzman, 1970; Lyle, 1973; Poston and Alvirez, 1973; Poston, Alvirez, and Tienda, 1976) are about one national origin group-Mexicans-to the neglect of other Hispanic groups. The work of Carliner (1976) is an early exception, although several studies produced during the last 2 or 3 years have begun to fill this research gap (see Tienda, 1981b, for a review of recent studies).

Most researchers depict the relationship between education and earnings as a linear function without considering the possibility and significance of a non-linear pattern of association. An exception is the suggestion by Featherman and Hauser (1978, Chap. 8) that a spline function more accurately represents the relationship between education and earnings among Mexican men. However, they said nothing about other potential models of the education-earnings relationship, nor did they comment on the pattern of relationship for other Hispanic groups. Existing studies provide only scattered clues about the pattern of relationship between graded schooling and earnings among Hispanics and little insight as to what factors give rise to the differentials among the various national origin groups. ${ }^{1}$ Pursuing this question for Hispanic men is worthwhile because studies of white and black men have shown the existence of credential effects (Taubman and Wales, 1973; Schwartz and Williams, 1979; Goodman, 1979) and different returns to education for major levels of schooling (Hansen, 1970; Farley, 1979; Olneck, 1979; Goodman, 1979). Accordingly, in this paper we attempt to specify how education influences the earnings of Hispanic men by documenting differentials in the pattern of relationship and contrasting the economic returns to educational achievement for various Hispanic nationalities.

\section{RECONCEPTUALIZING EDUCATION EFFECTS}

Single years of education is the most widely used specification of schooling in empirical human capital and status attainment research (Hauser, 1972; Hansen and Weisbrod, 1972; Blinder, 1973; Mincer, 1974; Taubman, 1976; Carliner, 1976). In some ways the conventional specification of education may appear to be overly simple, but it should not be discounted on either statistical or theoretical grounds because it is

\footnotetext{
1 Hispanic is a generic term for individuals of Spanish origin, but our research, like most recent studies, emphasizes the diversity among national origin groups and the need to distinguish among them. Unfortunately, due to small sample sizes of Cubans and Central/ South Americans, we combined these two groups into a single category; our results using the combined group are virtually identical to those obtained using separate groups except that our point estimates which bordered on statistical significance using separate groups are more reliable when the groups are combined.
} 
adequate for generating information needed to answer questions about individual returns to schooling. While the assumption of linearity provides parsimony (Lewis-Beck, 1980, p. 13), at times it is not justified.

Most researchers avoid nonlinear specifications because of the difficulty of deriving substantively meaningful breakpoints for the relationships. Although this problem is real in much social science research, it is less problematic for study of the relationship between education and earnings because there are natural breaks in schooling cycles (primary, high school, and college) where one might expect deviations from linearity to occur. First, the earnings payoff for each year of elementary schooling might be lower than that corresponding to a year of college due to the greater amount and quality of input in higher education as compared to elementary schooling (Schultz, 1963; Bowman, 1970). Second, because the supply of persons with some college is lower than that for persons with secondary or elementary schooling, this tends to bid up the wage levels of the college-educated population (Hansen, 1970). Third, the completion of a schooling level may confer bonuses on graduates in the form of a credentialing effect (Goodman, 1979). Essentially this means that the acquisition of a diploma is an important determinant of earnings, above and beyond school attendance leading to completion of specific grades.

Thus, while a linear specification of education has many desirable properties, among them a parsimonious and straightforward evaluation of economic rewards, nonlinear patterns also have substantive and empirical appeal. Goodman (1979, pp. 269-283) has identified several alternative specifications ${ }^{2}$ which we briefly summarize below and in Table 1:

(1) The linear model. In this conventional model, private economic benefits derive from education in a continuous linear fashion so that a unit change in education is accompanied by a fixed rate of return in earnings.

(2) The level-specific model. This specification permits the payoff to education to vary with the level of education, so that the rate of return for a year of elementary school is not the same as that for the completion of a year of high school, college, or graduate school.

(3) The credential model. This model indicates that the completion of

${ }^{2}$ Goodman proposed four alternatives to the linear model-those three we estimate, plus a pure credential model. However, the latter is neither theoretically nor substantively meaningful because it is incorrect to postulate that individuals receive bonuses for the completion of major schooling levels without also considering the incremental gains that make the completion of each schooling level possible. In other words, one cannot ignore the fact that to achieve a primary school credential, grades 1 through 6 must be completed. To evaluate individuals only in terms of credential effects ignores the fact that individuals with some schooling-even if less than 6 years-usually have more skills than those with only 2 years. Thus, we only estimate the three alternative models which are theoretically and substantively viable. 
TABLE 1

Operationalization of Education Levels to Represent Linear Levels and Credential Effects

\begin{tabular}{ll}
\hline $\begin{array}{l}\text { Variable and } \\
\text { type of effect }\end{array}$ & \multicolumn{1}{c}{ Operationalization } \\
\hline $\begin{array}{l}\text { Linear effects } \\
\text { Education } \\
\text { Levels effects }\end{array}$ & Total years of education \\
Elem & Number of years of elementary education, maximum is 8 years \\
High & Number of years of high school education, maximum is 4 years \\
Coll & Number of years of college education, maximum is 4 years \\
Credential effects & \\
Elem cred & Equal to 1 if completed 8 years of elementary education \\
High cred & Equal to 1 if completed 4 years of high school education \\
Coll cred & Equal to 1 if completed 4 years of college education \\
\hline
\end{tabular}

major levels of schooling (i.e., elementary school, high school, college, and graduate school) are in and of themselves important determinants of earnings. From a credentialist perspective, schooling is a screening device which certifies that individuals who have successfully completed a given level possess certain qualities (skills, ability) that should be rewarded. This specification combines the notion that each year of educational investment yields the same rate of return with the view that there are economic bonuses attached to the completion of each major level of schooling.

(4) The level-specific/credential model. This composite model allows each completed year of schooling to be rewarded differently according to level, and allows for benefits to be associated with each credential. It combines the features of Models 2 and 3.

Goodman has empirically assessed the explanatory value of these models in a study of white men. He finds substantial differences in the explained variance among the models, and that the linear specification of schooling, by far the most prevalent in empirical research, yields one of the worst fits to his data (Goodman, 1979, p. 278). Goodman rightly points out that not only is its explanatory value low relative to nonlinear specifications, but problems of interpretation can occur when contrasting two populations whose mean levels of educational attainment vary.

An example based on a comparison of the returns to education for blacks and whites illustrates this point. Such analyses actually compare the returns to education between two groups with different attainment levels. Black males aged 25 and over are concentrated in the two lower levels of the education distribution, with $49 \%$ having completed 8 or fewer years, and $43 \%$ having finished 9 to 12 years of schooling. White males are much more evenly distributed across these major schooling 
levels, with $26 \%$ having 8 or fewer years of education, $26 \%$ having attended college, and $48 \%$ having completed 9 to 12 years of school (U.S. Bureau of the Census, 1973b, p. 3). Consequently, the average white return to education is more heavily weighted by the high returns which accrue to college-educated persons than is true for blacks. Likewise, the white slope is not as heavily weighted by the poor returns found among elementary school dropouts.

In short, interpretation of results based on a linear specification could be ambigious. It may be that black men receive comparable rewards for each year of training relative to white men, but because of their different educational composition, their overall return to schooling will appear lower than that of the more highly educated white population. Alternatively, black workers may receive lower payoff to high school or elementary schooling than that which accrues to white men. Most studies professing to differentiate between these competing explanations have not been successful because they compare slopes that are not strictly comparable due to the divergent educational distributions of the groups.

In addition to clarifying differences in the patterns of relationships between schooling and earnings, the four models also allow for various substantively important nonlinearities: different slopes within different levels of schooling, and credential effects for the completion of major educational levels. Thus, this research potentially can provide new insights about how Hispanic origin groups, who are known to differ greatly in their socioeconomic and demographic characteristics (Jaffe, Cullen, and Boswell, 1980; Newman, 1978); also differ in their ability to translate educational attainment into earnings.

\section{DATA}

The present analysis is based on the 1976 Survey of Income and Education (SIE). In selecting our sample, we imposed a series of constraints to ensure that the resulting subpopulations were closely comparable on pertinent labor force characteristics. The sample includes all Hispanic men aged 18-64 who were in the labor force in 1975, and who earned at least $\$ 100$ during the year, but excludes individuals enrolled in school or the military in 1975 because these activities would temporarily depress their earnings. Individuals with missing data on occupations and industry in 1975 were also excluded. In all, 3191 Hispanic men are in our sample, including 1920 Mexicans, 337 Puerto Ricans, 179 Cubans, 186 Central/ South Americans, and 569 workers of other Spanish origin. A sample of 15,724 non-Hispanic whites serves as a comparison, and to verify earlier findings by Goodman (1979).

\section{MODEL SPECIFICATION}

Although there has been some tendency to emphasize similarities among Spanish origin populations, there are also several noteworthy differences 
that directly influence their labor market position. Specifically, the national origin groups differ with respect to social background, regional concentration, foreign birth composition, years of labor market experience, and labor market location, to name only a few. These differences influence labor market outcomes and thus must be taken into account to assess the net effects of education on earnings. Some concrete illustrations help visualize this point.

Both immigrant and U.S.-born Mexican origin men come from predominantly low socioeconomic backgrounds (Hirschman, 1978). Also, the farm origin of many Mexican men results in truncated schooling careers (Tienda, 1981a), and lowers their payoffs to cducation. In this respect, Mexicans differ notably from Cubans and Central/South Americans. The Cubans in our sample, who migrated to the United States between 1959 and 1964, were generally from middle-class backgrounds (Portes, 1978; Sullivan and Pedraza-Bailey, 1979), and therefore might be expected to reap higher economic rewards from schooling than Mexican or Puerto Rican origin men.

As shown in Table 2, the Hispanic origin groups differ notably in their educational characteristics. Central/South Americans (which includes Cubans) and other Spanish men were the most highly educated Hispanics, while men of Mexican and Puerto Rican origin completed the fewest years of graded schooling, averaging 9.3 and 10.1 years, respectively. Non-Hispanic white men had the highest level of educational attainment. with an average of just over 12.5 years of school. Less than one half of Mexican and Puerto Rican men had graduated from high school and only $5 \%$ had college degrees. In contrast, $19 \%$ of Central/South American origin men have graduated from college. Because there are so few collegeeducated Mexican and Puerto Rican men they might receive a special premium for the completion of an undergraduate degree, above and beyond that which accrues to the more highly educated Hispanic and non-Hispanic whites.

The significance of birthplace for Hispanic earnings can be linked to income through education. However, it is important to differentiate between schooling obtained in the United States and abroad because of underlying differences in the content and quality of education. Cuban and Central/ South Americans are considerably more likely to have acquired their education outside the United States than either Mexicans or Puerto Ricans because they are, in the main, first-generation immigrants (see Table 2), and many migrated to the United States as adults. Consequently, their earnings-education relationships could be heavily weighted by the lower rates of return that often accrue to the foreign-born (Chiswick, 1978; Tienda and Neidert, 1980). For Puerto Ricans, the significance of place of schooling, i.e., the mainland or the island, is more ambiguous because English is used in Puerto Rican schools, and many school curricula are 
TABLE 2

Mean Values of Variables Used in Regression Equations for Men Aged 18-64; NonHispanic Whites and Hispanics by National Origin

\begin{tabular}{|c|c|c|c|c|c|}
\hline \multirow[b]{2}{*}{ Variable } & \multicolumn{5}{|c|}{ National origin } \\
\hline & $\begin{array}{c}\text { Non-Hispanic } \\
\text { white }\end{array}$ & Mexican & $\begin{array}{l}\text { Puerto } \\
\text { Rican }\end{array}$ & $\begin{array}{c}\text { Central/South } \\
\text { American }^{\circ}\end{array}$ & $\begin{array}{l}\text { Other } \\
\text { Spanish }\end{array}$ \\
\hline \multirow[t]{2}{*}{ Education } & 12.55 & 9.35 & 10.06 & 11.41 & 11.29 \\
\hline & $(2.61)$ & $(4.13)$ & $(3.26)$ & $(3.66)$ & $(3.10)$ \\
\hline \multirow[t]{2}{*}{ Elem } & 7.92 & 6.79 & 7.39 & 7.52 & 7.69 \\
\hline & $(.54)$ & $(2.14)$ & $(1.57)$ & $(1.16)$ & $(1.01)$ \\
\hline \multirow[t]{2}{*}{ High } & 3.40 & 2.10 & 2.34 & 2.76 & 2.87 \\
\hline & $(1.26)$ & $(1.85)$ & $(1.73)$ & $(1.70)$ & (1.64) \\
\hline \multirow[t]{2}{*}{ Coll } & 1.22 & .46 & .33 & 1.12 & .74 \\
\hline & $(1.65)$ & $(1.08)$ & (.89) & $(1.62)$ & $(1.39)$ \\
\hline \multirow[t]{2}{*}{ Elem cred } & .96 & .68 & .82 & .83 & .88 \\
\hline & $(.18)$ & $(.47)$ & $(.38)$ & $(.38)$ & $(.32)$ \\
\hline \multirow[t]{2}{*}{ High cred } & .78 & .44 & .45 & .60 & .63 \\
\hline & $(.41)$ & $(.50)$ & $(.50)$ & $(.49)$ & $(.48)$ \\
\hline \multirow[t]{2}{*}{ Coll cred } & .22 & .06 & .03 & .19 & .12 \\
\hline & $(.41)$ & $(.23)$ & $(.18)$ & $(.40)$ & $(.33)$ \\
\hline \multirow[t]{2}{*}{ Years of work experience } & 19.87 & 18.10 & 19.00 & 19.93 & 20.65 \\
\hline & $(13.58)$ & $(12.73)$ & (12.38) & $(11.77)$ & (12.93) \\
\hline \multirow[t]{2}{*}{$(\text { Experience })^{2}$} & 579.21 & 489.58 & 513.90 & 535.41 & 593.43 \\
\hline & $(606.67)$ & $(564.04)$ & (549.15) & $(519.59)$ & (572.41) \\
\hline \multirow[t]{2}{*}{ Weeks worked in 1975} & 47.67 & 45.70 & 45.53 & 46.51 & 47.13 \\
\hline & $(9.96)$ & $(11.86)$ & $(11.69)$ & $(10.78)$ & $(10.41)$ \\
\hline \multirow{2}{*}{ Area wage rate } & 5.15 & 4.85 & 5.62 & 5.31 & 5.05 \\
\hline & $(.61)$ & $(.72)$ & $(.36)$ & $(.54)$ & $(.68)$ \\
\hline \multirow[t]{2}{*}{ Married } & .75 & .71 & .74 & .72 & .72 \\
\hline & $(.43)$ & $(.45)$ & $(.44)$ & $(.45)$ & $(.45)$ \\
\hline \multirow[t]{2}{*}{ Foreign born } & .05 & .33 & .75 & .96 & .28 \\
\hline & $(.21)$ & $(.47)$ & $(.43)$ & $(.19)$ & $(.45)$ \\
\hline \multicolumn{6}{|l|}{ Years since migration ${ }^{b}$} \\
\hline \multirow[t]{2}{*}{1 Year or less } & .02 & .02 & .01 & .03 & .00 \\
\hline & $(.14)$ & $(.14)$ & $(.12)$ & $(.17)$ & - \\
\hline \multirow[t]{2}{*}{$1-4$ Years } & .00 & .08 & .05 & .16 & .05 \\
\hline & - & $(.27)$ & $(.22)$ & $(.37)$ & $(.21)$ \\
\hline \multirow[t]{2}{*}{$5-9$ Years } & .01 & .08 & .10 & .36 & .10 \\
\hline & $(.09)$ & $(.27)$ & $(.30)$ & $(.48)$ & $(.31)$ \\
\hline \multirow[t]{2}{*}{10 Years or more } & .02 & .15 & .59 & .41 & .12 \\
\hline & $(.12)$ & $(.36)$ & $(.49)$ & $(.49)$ & $(.33)$ \\
\hline \multirow[t]{2}{*}{ Log earnings in 1975} & 9.25 & 8.78 & 8.88 & 8.91 & 9.08 \\
\hline & $(.82)$ & $(.84)$ & $(.70)$ & $(.90)$ & $(.74)$ \\
\hline Unweighted $(n)$ & $(15724)$ & $(1920)$ & (337) & $(365)$ & (569). \\
\hline
\end{tabular}

Note. Data are from weighted samples to render them comparable to the population. Standard deviations in parentheses.

a Includes Cubans.

- This variable is coded as a series of dummies. Native born are coded 0 on all the variables while the foreign-born are coded 1 on the variable indicating their arrival time in the United States and 0 on all the other variables. 
patterned after those used in the United States. Still, Puerto Ricans trained completely on the mainland tend to be more proficient in the use of English than their island-reared counterparts (see Tienda, 1981b, Chap. 8).

Chiswick (1978) has shown length of U.S. residence to enhance earnings as immigrants have greater opportunity to acquire skills and knowledge pertinent to the new labor market. However, the potentially adverse effect of foreign education may be especially important for individuals who acquired professional degrees outside the United States because the skills of jobs requiring special certification, such as those in teaching, law, or medicine, may not automatically be transferable from one country to another (Carliner, 1976). However, because the U.S. government aided many Cubans in recertifying their foreign degrees, any adverse influences that would ordinarily accrue to licensed professionals may have been attenuated by the time of this survey. Thus, the depressing effect of foreign education should be greatly diminished in these data, except among recent arrivals. To control for these effects we introduced a series of dummy variables which index year of migration to the United States, with the native born serving as the reference category. These dummies served as proxies for several variables which influence earnings, including familiarity with English, whether education was obtained abroad, and the time elapsed for acquisition of skills. ${ }^{3}$

A final noteworthy characteristic of Hispanic origin populations which has implications for their labor market experiences is regional concentration. This is important because of the well-established regional differences in industry structure, unemployment rates, unionization patterns, and wage rates. For example, the Northeast and the industrial Midwest have much higher proportions of their total labor force engaged in manufacturing than either the South or the Southwest (U.S. Bureau of the Census, 1973a, Table 298). Neidert (1980) has shown that as the proportion of the labor force engaged in manufacturing rises, income levels also increase,

\footnotetext{
${ }^{3}$ Rather than entering nativity as a dummy variable in the equations, we could present the results specific to both nativity and nationality. This would be appropriate if there were statistically significant nativity interactions to indicate that foreign birth results in lower payoffs to education, even after taking into account the generally less favorable characteristics found among the immigrant population. However. tests for interaction indicated that the underlying structure of the models for native and foreign-born workers was fundamentally the same, and that the observed differences were due to random sampling errors. For Mexican men, when eduction was specified linearly as years of schooling, tests for nativity interactions approached statistical significance. However, results from the other models showed that Mexican immigrants received as much monetary payoff from high school attendance or college graduation as their U.S.-born counterparts. This is an important finding, as it emphasizes the point made in the introduction-that many evaluations of the economic gain to schooling between two groups have been confounded by the fact that the levels of educational attainment vary between the two groups.
} 
while the degree of income inequality within the Anglo and Mexican populations decreases. Furthermore, her study shows that the income disparity between Anglo and Mexican families is inversely associated with the proportion of workers employed in manufacturing.

Thus, it is conceivable that other Hispanic origin groups who are concentrated in regions not dominated by manufacturing will have low returns to their educational attainment. In fact, due to the labor market structure in south Texas and rural northern New Mexico (Tienda, 1981a), Hispanic college graduates may experience difficulty locating well-paying jobs. This bodes ill for men of Mexican and other Spanish origin who are disproportionately concentrated in these regions. On the other hand, highly educated Puerto Rican workers who mostly reside in a region where the demand for skilled workers is great may reap greater rewards for college training. Alternatively, poorly educated workers who reside in areas where low-skilled jobs are declining may reap very limited economic rewards. For this reason, it is important to control for differences in wage rates corresponding to specific labor markets when studying the relationship between education and earnings for Hispanics.

The importance of regional concentration for the earnings of the various Hispanic origin groups is monitored by deflating earnings by the average wage rate of a labor market defined as Wages/(Hours $\times$ Weeks) within SMSAs or state level nonmetropolitan areas. Failing to do this would overestimate the effect of education for those individuals located in highwage regions and correspondingly diminish the returns to education of those individuals in low-wage regions (Borjas, 1981).

Many analysts delimit their samples to full-time earners who worked some minimum number of weeks in a given year. Rather than impose an additional constraint upon the already small subsample, we use weeks worked in 1975 as a control variable in each model. Other control variables used in the analyses are informed by the human capital literature. Human capital theory maintains that age-earnings profiles are concave from below because of the higher earnings achieved by more experienced workers (Blaug, 1976; Miller, 1960; Mincer, 1974). Our experience variable helps avoid exaggerating the effects of education, while its squared term models diminishing returns over time. We defined experience as age minus years of completed education minus 7 , unless workers' level of educational attainment was less than 7 years. In these instances, experience was computed as age minus 14 , to allow dropouts to begin working at the plausible age of $14 .^{4}$ A dummy for marital status controlled the systematic effects of marriage on earnings.

\footnotetext{
${ }^{4}$ Were this condition not imposed, we would have the situation of a third-grade dropout beginning employment at age 9 . While this is totally plausible for migrant farm workers. it is not officially recognized by the U.S. Census Bureau and Bureau of Labor guidelines.
} 


\section{RESULTS}

Table 3 reports the results of the estimation for the Hispanic and nonHispanic white groups. An incremental $F$ test computed over changes in explained variance by Models 2 through 4 indicates which specification best represents the education-earnings relationship for each group. ${ }^{5} \mathrm{We}$ do not report coefficients for the background and control variables in the interest of brevity, and to focus on the form of the functional relationship that best depicts differencs in the patterns of returns to education.

\section{The Form of the Education-Earnings Relationship}

Results in Table 3 indicate that for all except other Spanish men, the non-linear specifications significantly improved the explanatory power of the model, although the net increments to $R^{2}$ were small. ${ }^{6}$ Credential effects were especially important for Mexican, Central/South American, and non-Hispanic white men, because models that included payoffs for the completion of major levels of schooling (Models 3 and 4) generally produced higher adjusted $R^{2}$ values than did Model 1 for these groups. Thus, for these groups, the achievements of education credentials resulted in added income bonuses which the linear model was unable to show. For Cubans and Central/South Americans, completion of a college degree mattered most, while non-Hispanic whites and Mexican origin men received a bonus for the completion of high school as well.

The levels model (Model 2), which allows for different rates of return for each major schooling level, best predicted the earnings of Puerto Rican and other Spanish origin men, but the fit of this model was somewhat tighter for the Puerto Ricans. For non-Hispanic white and Mexican men

5 All models include years of education, or in the case of Models 2 and 4, its algebraic equivalent. Thus, each $F$ test tests the explanatory power of the additional education terms.

${ }^{6}$ Results of the incremental $F$ tests $\left(F d f a\right.$ dfb, $N$ dfa $=\left(R^{2} \mathrm{a}-R^{2} \mathrm{~b}\right) /\left(1-R^{2} \mathrm{a}\right) \times$ $(N-d f a /(d f a-d f b))$ comparing Models 2 through 4 against Model 1 are as follows:

\begin{tabular}{|c|c|c|c|c|c|}
\hline & $\begin{array}{c}\text { Non-Hispanic } \\
\text { white }\end{array}$ & Mexican & $\begin{array}{l}\text { Puerto } \\
\text { Rican }\end{array}$ & $\begin{array}{c}\text { Central/South } \\
\text { American }\end{array}$ & $\begin{array}{l}\text { Other } \\
\text { Spanish }\end{array}$ \\
\hline \multicolumn{6}{|c|}{2 vs 1} \\
\hline$R^{2}$ & .002 & .005 & .032 & .004 & .005 \\
\hline$F$ & $32.063^{* *}$ & $10.841^{* *}$ & $9.290^{* *}$ & 1.440 & $(2.957)^{*}$ \\
\hline \multicolumn{6}{|c|}{3 vs 1} \\
\hline$R^{2}$ & .004 & .011 & .026 & .012 & .001 \\
\hline$F$ & $42.923^{* *}$ & $16.111^{* *}$ & $4.963^{* *}$ & $2.919^{*}$ & .390 \\
\hline \multicolumn{6}{|c|}{4 vs 1} \\
\hline$R^{2}$ & $.004^{* *}$ & .011 & .033 & .012 & .007 \\
\hline$F$ & 25.751 & $9.657^{* *}$ & $3.804 * *$ & 1.741 & 1.654 \\
\hline
\end{tabular}

$* p \leqslant .05$ quantity in parentheses borders on statistical significance.

*** $p \leqslant .001$. 
TABLE 3

Unstandardized Regression Coefficients ${ }^{a}$ for Four Models of the Relationship between Education and Earnings for Men Aged 18-64: Non-Hispanic Whites and Hispanics by Natural Origin

\begin{tabular}{|c|c|c|c|c|c|}
\hline Model & $\begin{array}{c}\text { Non-Hispanic } \\
\text { white }\end{array}$ & Mexican & $\begin{array}{l}\text { Puerto } \\
\text { Rican }\end{array}$ & $\begin{array}{l}\text { Central/South } \\
\text { American }^{b}\end{array}$ & $\begin{array}{l}\text { Other } \\
\text { Spanish }\end{array}$ \\
\hline \multicolumn{6}{|l|}{ Model 1} \\
\hline Education & $.068^{* *}$ & $.043^{* *}$ & $.034^{* *}$ & $.060^{* *}$ & $.056^{* *}$ \\
\hline Constant & 5.103 & 5.146 & 6.961 & 5.128 & 4.760 \\
\hline Adjusted $R^{2}$ & 5.07 & .552 & .392 & .493 & .517 \\
\hline$R^{2}$ & .508 & .555 & .410 & .507 & .525 \\
\hline \multicolumn{6}{|l|}{ Model 2} \\
\hline Elem & $.051^{* *}$ & .016 & -.028 & .061 & .004 \\
\hline High & $.046^{* *}$ & $.050^{* *}$ & $.058^{* *}$ & .028 & $.069^{* *}$ \\
\hline Coll & $.085^{* *}$ & $.088^{* *}$ & $.125^{* *}$ & $.095^{* *}$ & $.077^{* *}$ \\
\hline Constant & 5.302 & 5.291 & 7.211 & 5.172 & 5.098 \\
\hline Adjusted $R^{2}$ & .509 & .558 & .421 & .494 & .520 \\
\hline$R^{2}$ & .510 & .560 & .442 & .511 & .530 \\
\hline \multicolumn{6}{|l|}{ Model 3} \\
\hline Education & $.033^{* *}$ & .029 & .015 & .000 & $.047^{*}$ \\
\hline Elem cred & .001 & -.099 & -.107 & .228 & -.038 \\
\hline High cred & $.085^{* *}$ & $.131^{* *}$ & $.190^{*}$ & .086 & .066 \\
\hline Coll cred & $.212^{* *}$ & $.299^{* *}$ & $.426^{* *}$ & $.425^{* *}$ & .058 \\
\hline Constant & 5.440 & 5.253 & 7.089 & 5.517 & 4.844 \\
\hline Adjusted $R^{2}$ & .512 & .563 & .413 & .501 & .515 \\
\hline$R^{2}$ & .512 & .566 & .436 & .519 & .526 \\
\hline \multicolumn{6}{|l|}{ Model 4} \\
\hline Elem & $.074^{* *}$ & $.035^{* *}$ & -.020 & .009 & -.025 \\
\hline Elem cred & -.060 & -.112 & -.029 & .207 & .149 \\
\hline High & .009 & .022 & .041 & -.002 & .053 \\
\hline High cred & $.142^{* *}$ & $.159^{* *}$ & .078 & .092 & .017 \\
\hline Coll & $.036^{* *}$ & .012 & .097 & -.003 & $.111^{* *}$ \\
\hline Coll cred & $.203^{* *}$ & $.356^{* *}$ & .141 & $.435^{* * *}$ & -.165 \\
\hline Constant & 5.217 & 5.228 & 7.197 & 5.467 & 5.213 \\
\hline Adjusted $R^{2}$ & .512 & .562 & .417 & .498 & .519 \\
\hline$R^{2}$ & .512 & .566 & .443 & .519 & .532 \\
\hline$(\mathrm{N})$ & (15724) & $(1920)$ & (337) & (365) & $(569)$ \\
\hline
\end{tabular}

${ }^{a}$ Control variables are years of work experience, experience squared, weeks worked in 1975, area wage rate, marital status, and a series of dummy variables to reflect years since migration for the foreign-born.

${ }^{b}$ Includes Cubans.

* Significant at $\leq .05$, one-tailed test.

** Significant at $\leq .01$, one-tailed test.

the levels model also provided a better fit to the data than did the linear model, while for Puerto Rican men the credential model produced significantly higher $R^{2}$ values than did Model 1. However, the levels model was not the "best" model for non-Hispanic white or Mexican workers; nor were credential effects as important for men of Puerto Rican ancestry as are differential payoffs for each level of schooling. It was somewhat 
surprising that for these three groups, Model 4 did not fare somewhat better as it allows for both levels and credential effects. We later discuss why this result emerges.

\section{Differences in the Payoffs to Educational Attainment}

In the previous section we illustrated how education was translated into earnings for Hispanic and non-Hispanic men. For all the Spanishspeaking groups, a linear derivation appears to be less suitablc than the more complicated models, but it has the advantage of parsimony, which is an important consideration for analyses of small samples. That the relation between education and earnings is statistically similar among three of the five groups does not mean that the monetary gains from education for each of these groups cannot diverge. This is well illustrated by the point estimates for Models 2 through 4 which emphasize the nature of the differences.

With earnings depicted as a simple linear function of years of schooling. Puerto Rican men reaped the lowest return to education. The partial effect of each year of graded school was $4.3 \%$ for Mexican men, compared to $3.4 \%$ for Puerto Rican men. The other Hispanic origin populations fared somewhat better, particularly men of Cuban and Central/South American ancestry, who averaged a $6 \%$ increase in earnings for each completed year of schooling. This rate of return was only slightly lower than that of non-Hispanic white men. The difference in the payoff to schooling between Puerto Rican and Mexican men on the one hand, and the more highly educated groups on the other, partly reflects the large proportions of elementary and high school dropouts among the former populations (see Table 2).

As Model 2 shows, with a slight departure for non-Hispanic whites, the payoff to elementary schooling was lower than the return to high school. For all groups the returns to college surpassed the payoffs to secondary school. This systematic pattern evident for Hispanic and nonHispanic origin men, provides support for the argument that the large proportion of poorly educated Puerto Ricans and Mexicans lessens the average return to years of schooling for these three groups. In other words, the fact that Mexicans and Puerto Ricans enjoyed a sizable bonus for the completion of high school, and received substantial monetary payoffs for college attendance and/or graduation was not apparent in the model that depicted earnings as a linear function of years of education. Furthermore, while Mexican and Puerto Rican men appeared similar with the linear specification, the levels model showed that Puerto Rican men received higher returns to college than Mexican men. However, because of the less favorable educational profile of Puerto Rican men, their average annual return for each year of schooling was less than Mexican men (3.4 vs $4.3 \%$ ). 
The linear specification could be used to support conclusions that investment in education was not as profitable for Mexican and Puerto Rican youth compared to Central/South American or non-Spanish white youth. However, the models that allowed for different rates of return according to schooling levels, or the addition of monetary bonuses for the completion of intermediate and final grade levels, showed that it is rational for Hispanic men to invest in all levels of schooling, but especially high school and college. Hansen (1970, pp. 13-15) has stated this point quite succinctly: Because schooling is a "sequential process, requiring the completion of lower levels of schooling prior to the higher levels . . . [to] achieve a high rate of return at say the completion of high school, a steady flow of students through the lower and intermediate grades is essential, even though the rates of return at these levels may be much lower." Yet, it is precisely at the intermediate schooling levels that Hispanics, particularly Mexicans and Puerto Ricans, experience greatest difficulties, and these frequently result in higher dropout rates.

In fact, the returns to elementary education were exceptionally low for Hispanic origin men. In no instance were the coefficients for the returns to elementary school statistically different from zero for Hispanic men. In contrast, non-Hispanic men received a return to elementary schooling which was slightly higher than that received for high school, but no group received an extra monetary bonus for completion of elementary school (Model 3). Goodman's (1979) study of white men likewise showed the partial effect of an additional year of elementary school to be near 5\% (Model 2), thus reinforcing our results. This high return to elementary school for non-Hispanic men could result from the tendency for many low-skilled (education) men to belong to unions.

If elementary education rendered limited monetary benefits to most Hispanic workers, the reverse was true for college attendance and/or graduation. For all Hispanic men, college attendance was handsomely rewarded, and for Puerto Ricans and Central/South Americans, the payoff was substantial. All groups in our sample enjoyed at least a $7.5 \%$ return for each year of postsecondary schooling, while Puerto Rican and Central/ South American men reaped even greater rewards for college attendance, with the partial effect of each year of college education averaging 10 to $12 \%$. Only other Spanish origin men received rates of return to college lower than non-Hispanic whites.

Model 3 emphasizes the importance of college graduation for these same men. For example, Central/South American college graduates earned roughly $43 \%$ more than their counterparts without this credential. However, it is not clear from either of these models whether the benefits to college education are centered in the attainment of the college credential (Model 3 ), or in the mere acquisition of some college (Model 2 suggests this), or both. Thus we turn to Model 4, which allows for different returns 
according to schooling level, and different bonuses for the completion of these major school transitions.

From Model 4 it is clear that for Mexican men, only high school and college graduates achieve significantly higher earnings. A Mexican man who attended college but did not complete it earned about the same as a high school graduate, but non-Hispanic white men with some college earned more than high school graduates. Similarly, the mere attendance of college brought Puerto Rican and other Spanish origin men financial gains, but these two groups did not enjoy an added bonus for a baccalaureate degree as did non-Spanish whites. This is not to say that these two groups did not benefit from the completion of college; they did. But, the credential effect was no larger than the relative difference in earnings corresponding to each additional year of college. In effect, there was no extra bonus above and beyond the level-specific rates of return, which were substantial by themselves. Mexican men fell between these two patterns, because they received a significant financial gain for college graduation, but not from mere college attendance.

\section{DISCUSSION}

This research has shown that the level-specific, credentialist, and levelspecific/credentialist models provide new insights about the bonuses associated with the completion of important educational thresholds and the differential payoffs to elementary, secondary, and college education among Hispanic origin men. These effects, when they are present, cannot be discerned with the linear model. Thus, while the linear model is clearly the most parsimonious specification, it conceals some important aspects of variation among the national origin groups which are needed for fine tuning information provided to would be labor market entrants. The decision about whether to seek additional schooling to enhance labor market success clearly depends upon the schooling level in question, and the national origin of the individual.

Model 4 conceivably could help sort out questions such as whether the completion of 16 years of education is rewarded above and beyond the average returns to college attendance, but it is clear that this model also has some serious shortcomings. The most striking was the lack of significance of most of the coefficients. Among the Hispanics, only Mexican men have more than one significant term, but the sample sizes surely contributed to this situation. Results for the comparison group-nonHispanic whites-are testimony to this fact. One practical implication of our results is that this complex model may be problematic when the sample size is small. Nevertheless, the model is suggestive and deserves further scrutiny with data sets that are not fraught with the special design problems characteristic of the SIE (see Tienda, 1981b, Chap. 1). Public 
use samples from the 1980 census will provide a sound basis for reevaluating our results.?

Future analysts should not be overly enthusiastic about the virtues of the linear specification because it masks many of the differences among the Hispanic origin groups, and in comparison with non-Hispanic whites. Using years of education to predict earnings, the linear model showed that Puerto Rican men reap the lowest monetary benefit from schooling; yet, the equation that included terms for the completion of the three major educational thresholds showed that Puerto Rican men received rather high returns to college education. Similarly, the more complicated models showed that only non-Hispanic men reaped a significant average return to each year of elementary education and that Mexican men received added bonuses for high school and college graduation, while men of Puerto Rican and other Spanish origin benefited financially from mere college attendance. It is worthwhile to determine whether the significant elementary school income effect for non-Hispanic men actually captures the effects of unionization, or whether discrimination against low-skilled minority workers is implied.

The extraordinarily large bonus to college attendance enjoyed by Puerto Ricans is striking, but it is not likely that college-educated Puerto Ricans will always enjoy this great economic incentive to go on to college. At some point the net returns for college may decline as the supply of Puerto Ricans with some college education increases (Perlman, 1973, pp. 89-90). In other words the current stock of Hispanics (especially Mexicans and Puerto Ricans) with some college education is relatively low (see Table 2), with the result that their wage levels are raised. Eventually, "this will trigger a response, often a belated one, as additional people seek to obtain the types of education most needed; the result is to eventually push earnings and the rate of return back down again" (Hansen, 1970 , p. 19).

While it is plausible that, as the proportion of Hispanics with college credentials increases, the demand for college dropouts will diminish so that only those who actually complete college will continue to reccive the substantial economic gains from college, this outcome is unlikely, given that this pattern is not observed for non-Hispanic whites. Of course, this does not mean that Hispanics should not pursue higher education. Just the opposite conclusion should be derived from our results. As Table

\footnotetext{
7 A note about sample sizes is in order. In some ways the small sample sizes of the Hispanic groups make it impossible to ascertain whether some of the more suggestive findings actually hold. On the other hand, too large a sample may lead one to emphasize substantively unimportant findings. Throughout this paper, the increment to $R^{2}$ and the education coefficients all have been significant for the non-Hispanic white population. However, if the sample size had been 1000 for this group rather than 15,000 , some of the coefficients and increments to $R^{2}$ would no longer be significant.
} 
2 clearly shows, there are significant gaps in the educational achievements of Hispanic origin groups which serve to preserve their disadvantaged labor market position. Until the rates of return to education can be made more uniform among minority and nonminority groups, the need to equalize schooling completion rates should remain on all policy agendas. The task of the researchers interested in the fate of the Hispanic population is to continue to remind policy makers of the persisting differentials, and their inevitable long-term consequences, through both innovative methodologies and comparative analysis. Accordingly, a parallel analysis based on the 1980 census should prove useful to verify our results.

\section{REFERENCES}

Becker, G. S. (1964), Human Capital, Columbia Univ. Press, New York.

Blalock, H. M. (1972), Social Statistics (2nd Ed.), McGraw-Hill, New York.

Blau, P. M., and Duncan, O. D. (1967). The American Occupational Structure, Wiley, New York.

Blaug, M. (1976), "The empirical status of human capital theory: a slightly jaundiced survey," Journal of Economic Literature 14, 827-855.

Blinder, A. A. (1973), "Wage discrimination: reduced form and structural estimates," Journal of Human Resources 8, 436-445.

Borjas, G. J. (1981), "Hispanic immigrants in the U.S. labor market: an empirical analysis," in Hispanic Origin Workers in the U.S. Labor Market: Comparative Analyses of Employment Outcomes, (Marta Tienda, Ed.), pp. 200-225, final report to the U.S. Department of Labor, Employment and Training Administration, October.

Bowman, M. J. (1970), "Economics of education," in Financing Higher Education: Alternatives for the Federal Government, (M. Orwig, Ed.), Amer. College Testing Program, Iowa City.

Carliner, G. (1976), "Returns to education for blacks, anglos, and five Spanish groups," Journal of Human Resources 11, 172-189.

Chiswick, B. (1978), "The effect of Americanization on the earnings of foreign-born men," Journal of Political Economy 86, 897-921.

Day, R. H. (1967), "The economics of technological change and the demise of the sharecropper," American Economic Review 57, 427-429.

Farley, R. (1979), "Racial progress in the last two decades: what can we determine about who benefited and why?" Paper presented at the annual meeting of the American Sociological Association, New York, August.

Farley, R., and Hermalin, A. (1972), "The 1960's: a decade of progress for blacks?" Demography 9, 353-370.

Featherman, D. L., and Hauser, R. M. (1978), Opportunity and Change, Academic Press, New York.

Flanagan, R. J. (1974), "Labor force experience, job turnover, and racial wage differentials," Review of Economics and Statistics 56, 521-529.

Fogel, W. (1966), "The effect of low educational attainment on incomes: a comparative study of selected ethnic groups," Journal of Human Resources 1, 22-40.

Goodman, J. D. (1979), "The economic returns of education," Social Science Quarterly 60, 269-283.

Grebler, L., Moore, J. W., and Guzman, R. C. (1970), The Mexican-American People, Free Press, New York.

Hansen, W. L. (1970), "Patterns of rates of return to investment in education: some international comparisons," University of Wisconsin, Madison, Institute for Research on Poverty, Discussion Paper 70-70. 
Hansen, W. L., and Weisbrod, B. A. (1972), "Human capital investment, schooling, and earnings: the role of experience," University of Wisconsin. Madison, Institute for Research on Poverty, Discussion Paper 182-73.

Hauser, R. M. (1972), "Socioeconomic background and returns to education," University of Wisconsin, Madison, Center for Demography and Ecology, Working Paper 72-31.

Hirschman, C. (1978), "Prior U.S. residence among Mexican immigrants," Social Forces 56, $1170-1202$.

Jaffe, A. J., Cullen, R. M., and Boswell, T. D. (1980), The Changing Dernography of Spanish Americans. Academic Press. New York.

Lewis-Beck, M. S. (1980), "Applied regression: an introduction," Sage University Paper Series on Quantitative Applications in the Social Sciences, 07-022, Sage Publications, Beverly Hills, Calif.

Lyle, J. (1973). "Factors affecting job status of workers with Spanish surnames," Monthly Labor Review 96, 10-16.

Miller, H. P. (1960), "Annual and lifetime income in relation to education," American Economic Review 50, 962-986.

Mincer, J. (1974), Schooling, Experience and Earnings, National Bureau of Economic Research, New York.

Morgenstern, R. D. (1973), "Direct and indirect effects on earnings of schooling and socioeconomic background," Review of Economics and Statistics 55, 225-233.

Neidert, L. (1980), "Industrial Diversification, Industrial Composition and Majority-Minority Income Inequality: Anglos, Blacks and Mexican-Americans, 1970," unpublished dissertation, University of Texas, Austin.

Newman, M. J. (1978), "A profile of Hispanics in the U.S. work force," Monthly Labor Review 101, 3-14.

Olneck, M. R. (1979), "The effects of education on occupational status and earnings," in The Determinants of Economic Success in America, (Christopher Jencks, Ed.), pp. 159-190, Basic Books, New York.

Perlman, R. (1973), The Economics of Education: Conceptual Problems and Policy Issues, McGraw-Hill, New York.

Portes, A. (1978), "Illegal immigration and the international system: lessons from recent legal immigrants to the United States," Social Problems 26, 425-438.

Poston, D. L., Jr., and Alvirez, D. (1973), "On the cost of being a Mexican American worker," Social Science Quarterly 53, 695-709.

Poston, D. L.. Jr., Alvirez, D., and Tienda, M. (1976), "Earnings differences between anglos and Mexican male workers in 1960 and 1970: changes in the 'cost' of being Mexican-American," Social Science Quarterly 57, 618-631.

Psacharopoulos, G. and Hinchliffe, K. (1973), Returns to Education: An International Comparison, Jossey-Bass, San Francisco.

Schwartz, J., and Williams, J. (1979), "The effects of race on earnings," in Who Gets Ahead? The Determinants of Economic Success in America (Christopher Jencks, Ed.), pp. 191-212, Basic Books, New York.

Schultz, T. W. (1963), The Economic Value of Education, Columbia Univ. Press, New York.

Sewell, W. H., and Hauser, R. M. (1975), Education, Occupation and Earnings: Achievement in the Early Career, Academic Press, New York.

Siegel, P. M. (1965), "On the cost of being a Negro," Sociological Inquiry 35, 41-57.

Sullivan, T., and Pedraza-Bailey, S. (1979), Differential Success among Cuban-American and Mexican-American Immigrants, Final Report to the U.S. Department of Labor. Employment and Training Administration.

Taubman, P. J. (1976), "Earnings, education, genetics and environment," Journal of Human Resources 11, 446-461. 
Taubman, P. J., and Wales, T. J. (1973), "Higher education, mental ability and screening." Journal of Political Economy 81, 28-55.

Thurow, L. (1969). Poverty and Discrimination Brookings Institute, Washington DC.

Tienda. M. (1980), "A socioeconomic profile of Hispanic American male workers: perspectives on labor utilization and earnings," in Proceedings of the National Symposium on Hispanics and CETA, 1980 (Antonio Furino, Ed.) pp. 125-67, The Human Management and Development Program. College of Business, UTSA. San Antonio.

Tienda, M. (1981), "The Mexican American population." Nonmetropolitan America in Transition (A. Hawley and S. M. Mazie. Eds.) pp. 502-548. Univ. of North Carolina Press, Chapel Hill. (a)

Tienda, M. (1981), Hispanic Origin Workers in the U.S. Labor Market: Comparative Analyses of Employment Outcomes, National Technical Information Service, Springfield. Va. (b)

Tienda, M. (1982) "Socioeconomic and labor force characteristics of U.S. immigrants: issues and approaches, " in U.S. Immigration and Refugee Policy: Global and Domestic Issues (Mary Kritz, Ed.), pp. 211-231, Heath, Lexington, Mass.

Tienda, M., and Neidert, L. (1980), "Segmented markets and earnings inequality of native and immigrant Hispanics in the United States," in 1980 Proceedings of the American Statistical Association, Social Statistics Section, pp. 72-81, American Statistical Association. Washington, DC.

U.S. Bureau of the Census (1973), Census of Population: 1970, Vol. 1, Characteristics of the Population, Part I, United States Summary-Section 2, U.S. Gov. Printing Office, Washington, DC. (a)

U.S. Bureau of the Census (1973). Census of Population: 1970, Vol 1, Characteristics of the Population, Part II. Florida-Section 1, U.S. Gov. Printing Office, Washington, D.C. (b)

U.S. Bureau of the Census (1973), Census of Population: 1970, Subject Reports: Final Report PC(2)-1C, Persons of Spanish Origin, U.S. Gov. Printing Office, Washington. DC. (c)

U.S. Bureau of the Census (1973), Census of the Population: 1970, Subject Reports: PC(2)1D, Persons of Spanish Surname, U.S. Gov. Printing Office, Washington, DC. (d)

U.S. Bureau of the Census (1973), Census of the Population: 1970, Subject Reports: PC(2)5B, Educational Attainment, U.S. Gov. Printing Office, Washington, DC. (e)

Weiss, L., and Williamson, J. G. (1972), "Black education, earnings, and interregional migration: some new evidence," American Economic Review 62, 372-383.

Weiss, R. D. (1970), "The effect of cducation on the earnings of blacks and whites." Review of Economics and Statistics 52, 150-159.

Wilson, K. L., and Portes, A. (1980) "Immigrant enclaves: an analysis of the labor market experience of Cubans in Miami," American Journal of Sociology 86. 293-319. 